\title{
Immobilization of $\gamma$-Glutamyl Transpeptidase from Equine Kidney for the Synthesis of kokumi Compounds
}

\author{
Margherita Bruni ${ }^{+},{ }^{[a]}$ Marina S. Robescu ${ }^{+[a]}$ Daniela Ubiali, ${ }^{[a]}$ Giorgio Marrubini, ${ }^{[a]}$ \\ Renzo Vanna, ${ }^{[b]}$ Carlo Morasso, ${ }^{[b]}$ Ilaria Benucci, ${ }^{[c]}$ Giovanna Speranza, ${ }^{[\mathrm{d}]}$ and \\ Teodora Bavaro*[a]
}

$\gamma$-Glutamyl transpeptidase from equine kidney (ekGGT, E.C. 2.3.2.2) is an intrinsic membrane enzyme which transfers the $\gamma$ glutamyl moiety of glutathione to amino acids and peptides, thus producing $\gamma$-glutamyl derivatives. An immobilization study of ekGGT was carried out with the aim to develop a robust biocatalyst for the synthesis of $\gamma$-glutamyl amino acids which are known as kokumi compounds. Heterofunctional octylglyoxyl-agarose resulted in a high immobilization yield and activity recovery ( $93 \%$ and $88 \%$, respectively). Immobilized

\section{Introduction}

The use of enzymes as biocatalysts in food, pharmaceutical and fine chemical industries has expanded significantly over the last decades. ${ }^{[1-3]}$ For a successful application of enzymes, these catalysts must be stable and fully functional under process conditions, which often differ from the cellular environment (temperature, presence of organic cosolvents, pH). ${ }^{[4,5]}$ Enzyme immobilization on solid supports is a widely used technique to stabilize proteins and improve their performance in synthetic applications. $^{[6-8]}$ As a consequence of an enhanced stability, immobilization allows for enzyme reusability over multiple

[a] M. Bruni, ${ }^{+}$Dr. M. S. Robescu, ${ }^{+}$Prof. D. Ubiali, Dr. G. Marrubini, Dr. T. Bavaro Department of Drug Sciences

University of Pavia

Viale Taramelli 12

Pavia l-27100 (Italy)

E-mail: teodora.bavaro@unipv.it

[b] Dr. R. Vanna, Dr. C. Morasso

Nanomedicine and Molecular Imaging Lab

IRCCS ICS Maugeri

Via Maugeri 10

Pavia I-27100 (Italy)

[c] Dr. I. Benucci

Department of Agriculture and Forestry Science (DAFNE)

University of Tuscia

Via S. Camillo de Lellis snc

Viterbo l-01100 (Italy)

[d] Prof. G. Speranza

Department of Chemistry

University of Milan

Via Golgi 19

Milan I-20133 (Italy)

$\left.{ }^{+}{ }^{+}\right]$These two authors contributed equally to this work.

Supporting information for this article is available on the WWW under https://doi.org/10.1002/cctc.201901464

This publication is part of a joint Special Collection with ChemBioChem on "Excellence in Biocatalysis Research". Please follow the link for more articles in the collection.
ekGGT retained more than $95 \%$ activity under reaction conditions (Tris- $\mathrm{HCl}, \mathrm{pH} 9,0.05 \mathrm{M}$ ) after 6 days, whereas the residual activity after 6 reaction cycles (18 days) was $85 \%$. The synthesis of $\gamma$-glutamylmethionine catalyzed by octyl-glyoxylagarose-ekGGT afforded the product in $42 \%$ yield $(101 \mathrm{mg})$. The immobilized ekGGT was characterized by Raman spectroscopy. The immobilization protocol developed for ekGGT could be of general applicability to membrane proteins.

catalytic cycles. Moreover, once the biocatalyst is bound to the support, it becomes a heterogenous catalyst, thus facilitating its separation from the reaction mixture and minimizing the risk of product contamination. Protein impurities associated with molecules synthesized by biocatalysis represent an issue in food and pharmaceutical processes. ${ }^{[5,9]}$ Many immobilization techniques have been developed, including absorption, entrapment, encapsulation, cross-linking and covalent binding. The optimal immobilization method has to be determined experimentally for each enzyme as it strongly depends on the biocatalytic process as well as on the enzyme itself. ${ }^{[10]}$ Most of immobilization protocols reported in literature are applicable to watersoluble enzymes but to a very less extent to membrane-bound proteins, which require a quite hydrophobic environment to preserve their catalytic activity. ${ }^{[11-13]}$

Integral membrane proteins (IMPs) represent $15-30 \%$ of all coding sequences in the genome of living organisms. ${ }^{[1,12]}$ IMPs play essential roles in living cells that can be exploited also ex vivo for biosensors, ${ }^{[14,15]}$ biocatalytic applications ${ }^{[16,17]}$ and energy production. ${ }^{[18]}$ The immobilization of membrane-bound proteins and the design of solid supports mimicking natural membranes are an active field of research. Liposomes, ${ }^{[19]}$ sol-gel materials ${ }^{[20]}$ and lipid crystalline cubic phases ${ }^{[21,22]}$ are some of the membrane mimetic-matrixes developed for IMP immobilization. By contrast, few examples of covalent immobilization have been reported to date. ${ }^{[17,23,24]}$

$\gamma$-Glutamyl-transpeptidases (GGTs, EC 2.3.2.2) catalyze the transfer of the $\gamma$-glutamyl moiety of glutathione (GSH) and other $\gamma$-glutamyl compounds to either water (hydrolysis) or natural and modified amino acids and peptides (transpeptidation), thus producing $\gamma$-glutamyl derivatives. ${ }^{[25-28]}$ GGTs are widely distributed in all living organisms from bacteria to mammals. Bacterial homologues are generally non glycosylated soluble proteins, which are localized in the periplasmic space or 
extracellular space, while mammalian GGTs are generally glycosylated IMPs. ${ }^{[29]}$

GGTs have been exploited as biocatalysts for the synthesis of various $\gamma$-glutamyl compounds with high added value such as $\gamma$-L-glutamyl-L-DOPA, $\gamma$-glutamyl-taurine, $\gamma$-D-glutamyl-L-tryptophan and $\gamma$-L-glutamyl-ethylamide (L-theanine). ${ }^{[30]}$ Moreover, $\gamma$-glutamyl derivatives of methionine and S-substituted alk(en)yl cysteines (i.e. methylcysteine, S-allylcysteine and S-trans-propenylcysteine) are known as kokumi compounds. Kokumi is a Japanese term that refers to taste perception defined as having mouthfulness, thickness and a long-lasting savory sensation. Although being nearly tasteless in themselves, kokumi compounds are able to elicit strong taste sensations, especially when associated with protein-rich food, thus acting as true flavor enhancers. ${ }^{[31,32]}$ Despite their simple chemical structure, the synthesis of $\gamma$-glutamyl derivatives through the classical peptide chemistry is troublesome due to the need of protection and deprotection steps. ${ }^{[3]}$ Therefore, an enzymatic approach does represent an appealing solution for their supply.

In this work, we described the immobilization study of equine kidney GGT (ekGGT) for the synthesis of kokumi peptides. A tailor-made immobilization protocol was set up by considering that ekGGT is a membrane enzyme and that it is potentially usable as biocatalyst in the food sector. The heterofunctional support octyl-glyoxyl (OCGLX)-agarose ${ }^{[34]}$ allowed for the immobilization of ekGGT in two steps: first, the hydrophobic core of the enzyme was absorbed and stabilized by the hydrophobic octyl chains of the support, thus mimicking lipids of cellular membranes, then, the covalent attachment of the enzyme through the aldehyde groups of the carrier stabilized the protein against potential enzyme leaching. Raman spectroscopy was used to characterize the molecular properties of native and immobilized ekGGT. Finally, the immobilized
ekGGT was used for the preparative synthesis of the kokumi substance $\gamma$-glutamylmethionine.

\section{Results and Discussion}

\subsection{Screening of Immobilization Carriers}

With the aim to develop a ekGGT-based biocatalyst suitable for preparative applications, this enzyme was immobilized on differently activated agarose carriers. Agarose beads, derived from a neutral gelling heteropolysaccharide, are porous, mechanically resistant, and highly hydrophilic. These features make this biopolymer an ideal carrier for enzyme immobilization. ${ }^{[35]}$

As a first approach, GLX-agarose (see Table 1 for abbreviations) was assayed. This carrier has been widely explored for the covalent immobilization of enzymes. ${ }^{[36-38]}$

Immobilization relies on the formation of imine bonds between the aldehyde groups of the carrier and the lysine $\varepsilon$ $\mathrm{NH}_{2}$ groups of the protein. The immobilization of ekGGT on GLX-agarose (Table 1, entry 1) gave a high yield in terms of immobilized protein ( $80 \%)$ and a good activity recovery (30\%).

Agarose is a versatile carrier since it can be easily functionalized by exploiting the reactivity of its hydroxyl groups.

Thus, we decided to explore an array of binding chemistry. The reactive groups of GA-EDA-agarose (Table 1, entry 2 ) are the same as in GLX-agarose. On the same binding chemistry, however, GA-EDA-agarose is characterized by a spacer that may impart a higher flexibility to the immobilized enzyme. In principle, this scenario could assist in minimizing the distortion of the protein upon immobilization, thus preserving the enzyme activity. ${ }^{[39]}$ The immobilization yield was $100 \%$ but, surprisingly,

\begin{tabular}{|c|c|c|c|c|c|c|}
\hline Entry & $\begin{array}{l}\text { Agarose-based- } \\
\text { carrier }^{[\mathrm{b}]}\end{array}$ & Functional group & $\begin{array}{l}\text { Activity } \\
{[U / g]}\end{array}$ & $\begin{array}{l}\text { Immobilization yield } \\
\text { [\%] }\end{array}$ & $\begin{array}{l}\text { Activity recovery } \\
{[\%]}\end{array}$ & $\begin{array}{l}\text { Efficiency } \\
{[\%]}\end{array}$ \\
\hline 1 & GLX & & 3.80 & 80 & 30 & 39 \\
\hline 2 & GA-EDA & & 0.21 & 100 & 3 & 3 \\
\hline 3 & GA-APTES & & 0.09 & 21 & 1 & 2 \\
\hline 4 & GPTS & & 0.17 & 37 & 1 & 6 \\
\hline 5 & $\mathrm{CDI}$ & & 0.01 & 14 & 1 & 7 \\
\hline 6 & $\mathrm{CNBr}$ & & 3.00 & 79 & 41 & 53 \\
\hline 7 & OCGLX & & 13.70 & 93 & 88 & 95 \\
\hline
\end{tabular}


the immobilized enzyme lost almost completely its activity (3\% activity recovery). An even poorer outcome was obtained by using GA-APTES-agarose (Table 1, entry 3).

When ekGGT was immobilized on an epoxy carrier (GPTSagarose), a moderate immobilization yield was achieved (37\%), but no activity was detected for the immobilized biocatalyst. A slight improvement was obtained when the enzyme was immobilized on Sepabeads $^{\mathrm{TM}}$ EC-EP/S (100\% immobilization yield, $18 \%$ activity recovery), an epoxy-functionalized carrier which is hydrophobic in nature (methacrylic polymeric matrix). This evidence highlighted that, on the same binding chemistry, a less hydrophilic carrier might be better tolerated by the enzyme. In order to enlarge the screening to a different binding chemistry, carbamate and isocyanate activation of the carrier was performed by treatment of agarose with $N, N^{\prime}$-carbonyldiimidazole (CDI) or $\mathrm{CNBr}$, respectively. In the former case, a scarce immobilization yield and a negligible activity recovery were obtained (Table 1, entry 5), whereas CNBr-agarose gave $85 \%$ immobilization yield and $41 \%$ activity recovery (Table 1 , entry 6).

The use of heterofunctional supports, that bear different types of active groups on the support surface, has been previously reported for the immobilization of three lipases (from Candida antarctica B, Thermomyces lanuginosus and Rhizomucor miehei), and the artificial phospholipase Lecitase Ultra. ${ }^{[34]}$ Specifically, OC-agarose was converted into OCGLXagarose. Cross-linked octyl-agarose beads have some diols (resulting from the opening of the epoxy moieties during carrier preparation) which may be easily oxidized to glyoxyl groups with periodate. ${ }^{[34]}$

We hypothesized that such a heterofunctional carrier might enhance the immobilization of ekGGT through a first mild, hydrophobic interaction involving the hydrophobic portion of the enzyme and the octyl chains (mimicking the natural environment of the protein), followed by a covalent interaction enzyme-carrier deriving from the formation of imine bonds. This two-step mechanism can thus answer the need to create a "favourable" microenvironment for ekGGT immobilization that prevents it from deactivation, also avoiding undesired enzyme leaching. Hydrophobic adsorption was carried out in phosphate buffer at $\mathrm{pH} 7$ and, after 3 hours, a $98 \%$ immobilization yield was obtained. Then, once ekGGT was adsorbed in a close proximity on the carrier surface, it was incubated at $\mathrm{pH} 10$ to promote the reactivity of lysine $\varepsilon-\mathrm{NH}_{2}$ groups towards the aldehyde groups of the carrier (Scheme 1). As a result, immobilization of ekGGT was almost complete (93\%) and a very high immobilization efficiency was obtained (95\%). In other words, all the enzyme in solution was immobilized and almost $100 \%$ of activity was found in the immobilized biocatalyst. $^{[10]}$

\subsection{Study of the Immobilization Process of ekGGT on OCGLX-Agarose}

A systematic study was undertaken in order to evaluate the critical factors that affected the immobilization of ekGGT on
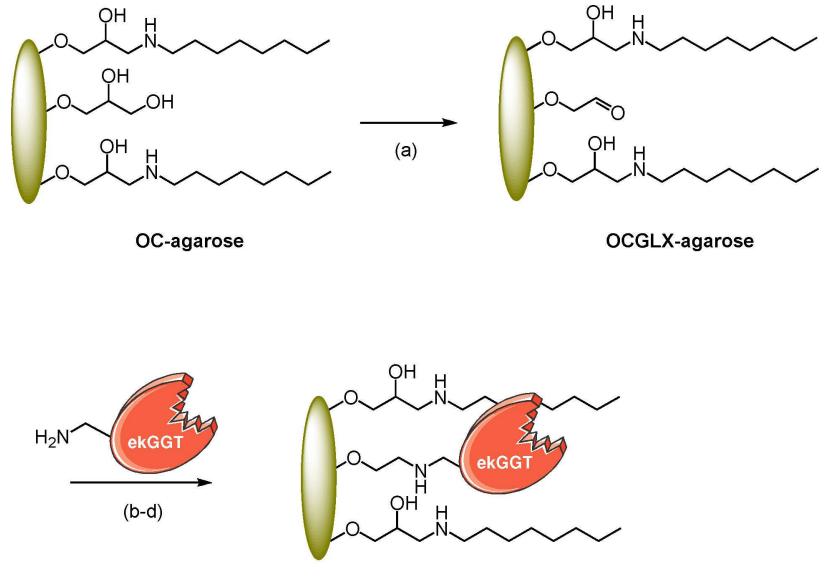

OCGLX-agarose-ekGGT

Scheme 1. Immobilization of ekGGT on OCGLX-agarose. Experimental conditions: (a) $35 \mu \mathrm{mol} \mathrm{NalO}_{4}$ per g carrier, r.t., $2 \mathrm{~h}$; (b) ekGGT (1 mg g $\left.{ }^{-1}\right), \mathrm{KH}_{2} \mathrm{PO}_{4}$

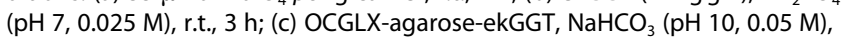
r.t., 3 h; (d) $\mathrm{NaBH}_{4}, \mathrm{pH}$ 10, 30 min.

OCGLX-agarose. The goal of this study was to set up a robust and reproducible method for this immobilization protocol by using an experimental design approach (DoE). Upon the critical revision of all the immobilization steps, six factors (storage time of the carrier $\mathrm{X} 1$, buffer volume $\mathrm{X} 2$, stirring system $\mathrm{X} 3, \mathrm{NaBH}_{4}$ addition $\mathrm{X} 4$, time of chemical reduction $\mathrm{X} 5$, drying time of the immobilized biocatalyst $\mathrm{X} 6$ ) were selected. One additional "Dummy" fictitious factor, used to assay the experimental variance, was included in the list of the process factors, as shown in the experimental plan reported in Table 2.

Eight experiments were thus planned by following a Plackett Burman 8-run design (Table 2), and one further independent validation experiment was carried out to confirm the results. The model hypothesized for the description of the immobilization outcome was a linear model without interactions, as from the general Equation (1):

$$
\begin{aligned}
& \mathrm{y}(\text { activity } \mathrm{U} / \mathrm{g})=\mathrm{b} 0+\mathrm{b} 1 \cdot \mathrm{X} 1+\mathrm{b} 2 \cdot \mathrm{X} 2+\mathrm{b} 3 \cdot \mathrm{X} 3+ \\
& \mathrm{b} 4 \cdot \mathrm{X} 4+\mathrm{b} 5 \cdot \mathrm{X} 5+\mathrm{b} 6 \cdot \mathrm{X} 6+\mathrm{b} 7 \cdot \mathrm{X} 7
\end{aligned}
$$

Three factors, namely the storage time of the carrier, the time of chemical reduction with $\mathrm{NaBH}_{4}$, and the drying time of the immobilized biocatalyst ( $\mathrm{X} 1, \mathrm{X} 5$ and $\mathrm{X} 6)$ resulted to be those affecting more than the others the immobilization outcome. As shown in Table 2 and Figure 1, the carrier storage at $4{ }^{\circ} \mathrm{C}(\mathrm{X} 1)$ was the most important factor. The activity of the immobilized enzyme was almost completely lost when the immobilization protocol was performed after 7 days from carrier preparation. The immobilization has to be carried out, indeed, after a maximum lag time of one day after the carrier preparation.

The second factor affecting the immobilization outcome was the time necessary for the chemical reduction with $\mathrm{NaBH}_{4}$ : the longer is the time of contact enzyme-reducing agent, the lower is the activity of immobilized ekGGT. Unspecific reduction of amino acid residues of the protein altering the three- 


\begin{tabular}{|c|c|c|c|c|c|c|c|c|}
\hline Exp\# & $\begin{array}{l}X_{1}^{[a]} \\
\text { [days] }\end{array}$ & $\begin{array}{l}X_{2}^{[b]} \\
{[\mathrm{mL}]}\end{array}$ & $X_{3}^{[c]}$ & $X_{4}^{[d]}$ & $\begin{array}{l}X_{5}^{[e]} \\
{[\mathrm{min}]}\end{array}$ & $\begin{array}{l}X_{6}^{[f]} \\
{[\mathrm{min}]}\end{array}$ & $X_{7}^{[g]}$ & $\begin{array}{l}Y^{[\mathrm{h}]} \\
{[\mathrm{U} / \mathrm{g}]}\end{array}$ \\
\hline 2 & 1 & 4 & Shaking & Solution & 30 & 10 & -1 & 13.70 \\
\hline 3 & 1 & 2 & Shaking & Solution & 60 & 3 & +1 & 9.97 \\
\hline 4 & 7 & 2 & Mechanical & Solid & 60 & 10 & -1 & 4.40 \\
\hline 5 & 1 & 4 & Mechanical & Solid & 60 & 10 & +1 & 14.38 \\
\hline 6 & 7 & 2 & Shaking & Solid & 30 & 10 & +1 & 8.35 \\
\hline 7 & 7 & 4 & Mechanical & Solution & 30 & 3 & +1 & 5.54 \\
\hline 8 & 1 & 2 & Mechanical & Solid & 30 & 3 & -1 & 12.74 \\
\hline
\end{tabular}

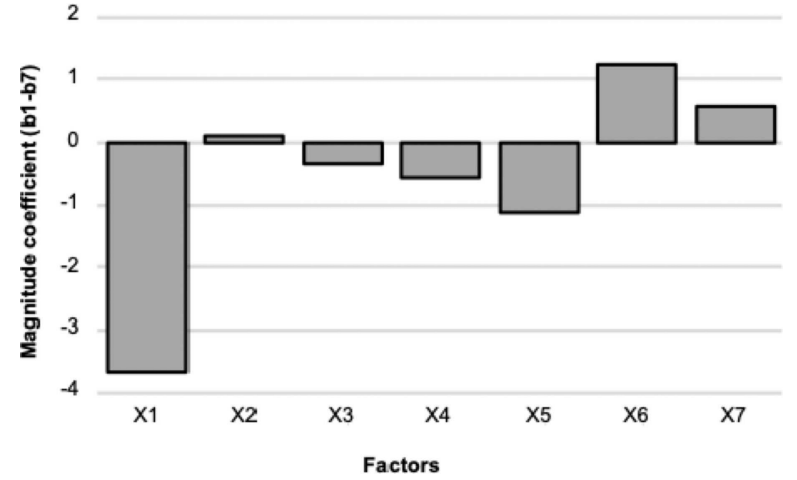

Figure 1. Results of Plackett-Burman design.

dimensional structure of ekGGT cannot be ruled out. Finally, the time necessary to dry out the immobilized enzyme before activity measurement also emerged as an important parameter. Agarose is a sharply hydrophilic polymer thus it can capture a considerable amount of water inside its polymeric matrix. The presence of water affects the weight of the immobilized biocatalyst, unless the drying step is standardized. It was found that 10 minutes for the s.v. filtration of the biocatalyst was sufficient to have reproducible results. The remaining 3 parameters, namely buffer volume ( 2 or $4 \mathrm{~mL}$ ), type of stirring (mechanical/shaking), $\mathrm{NaBH}_{4}$ addition (solid/solution), did not affect significantly the immobilization protocol. To confirm the reliability of the Plackett-Burman model, validation experiments were performed by keeping constant the significant factors (X1, $X 5$ and $X 6)$ and changing the negligible ones $(X 2, X 3, X 4, X 7)$. As shown in Table $\mathrm{S} 1$, the results were in good agreement with the predicted outcomes of the model.

\subsection{Molecular Characterization of OCGLX-Agarose-ekGGT by Raman Spectroscopy}

The OCGLX-agarose-ekGGT was further characterized by Raman spectroscopy for a deeper insight into the binding of the enzyme to the carrier in label-free through a direct, nondestructive approach.

The analysis was performed on the carrier as such, on the native enzyme, and on the immobilized enzyme by acquiring the single spectra. As shown in Figure $2 \mathrm{~A}$, both the enzyme and the carrier were characterized by specific Raman signals. ${ }^{[40]}$ In the enzyme spectrum (Figure 2A), vibrations associated to phenylalanine (aromatic stretching, $1002 \mathrm{~cm}^{-1}$ ), peptide bonds (amide $\mathrm{C}-\mathrm{N}, \mathrm{N}-\mathrm{H}, 1305 \mathrm{~cm}^{-1}$ ), aliphatic chains of amino acids $\left(\mathrm{CH}_{2}, 1447 \mathrm{~cm}^{-1}\right)$ and amino acids backbone $\left(\mathrm{C}=\mathrm{O}, 1631 \mathrm{~cm}^{-1}\right)$ have been detected, while in OCGLX-agarose spectrum typical signals related to mono- and disaccharides ( $\mathrm{C}-\mathrm{O}-\mathrm{C}, 848, \mathrm{C}-\mathrm{C}$, $\left.891, \mathrm{C}-\mathrm{O}, 1083 \mathrm{~cm}^{-1}\right)$ and signals that can be associated to the aliphatic chain $\left(\mathrm{CH}_{2}, 1454 \mathrm{~cm}^{-1}\right)$ are present. In the spectrum of the immobilized biocatalyst (Figure $2 \mathrm{~A}$ ), Raman signals of both ekGGT and OCGLX-agarose are consistent with the occurrence of an enzyme-carrier interaction (as highlighted by the shift of some Raman signals: $891,964,1077 \mathrm{~cm}^{-1}$ ).

Once the reference spectra of the two standards (i.e. native enzyme and carrier) were obtained and after the analysis of the spectrum of the immobilized biocatalyst, a Raman imaging mapping experiment was performed in order to explore a small portion (around $1.5-2 \mu \mathrm{m}$ of agarose microspheres) of the enzyme/OCGLX-agarose conjugate. As shown in Figure 2B, the surface of agarose beads is completely surrounded by the enzyme, thus suggesting a binding between the enzyme and support.

\subsection{Stability of Immobilized and Native ekGGT}

The stability of native ekGGT and OCGLX-agarose-ekGGT were evaluated under reaction conditions (Tris- $\mathrm{HCl}$ buffer, $\mathrm{pH}$ 9, $0.05 \mathrm{M} 4{ }^{\circ} \mathrm{C}$, in absence of substrate). The immobilized ekGGT was fully stable for 6 days, while the native enzyme retained $70 \%$ of its activity under the same incubation time (Figure 3).

Protein leaching assay on immobilized ekGGT was also performed. After 6 day-incubation under the reaction conditions, no release of the protein from the carrier was detected, as indicated by the absence of protein in the supernatant (see Experimental Section for details).

\subsection{Immobilized Biocatalyst Recycling}

Recycling of immobilized ekGGT was performed by evaluating over time the residual activity of the enzyme in the synthesis of 
A
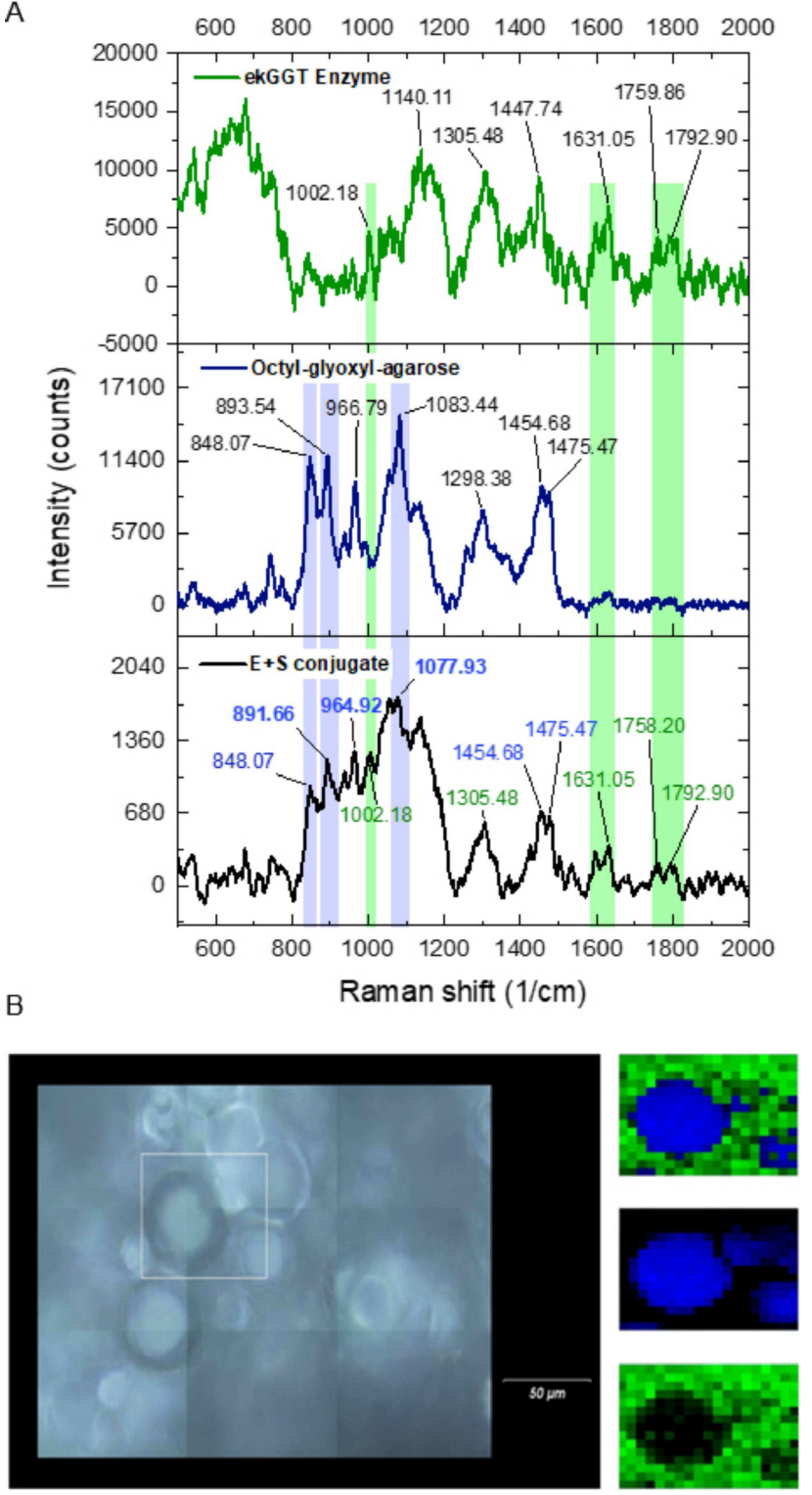

Figure 2. A) Representation of Raman spectra. Green bands represent the enzyme specific signals. Blue bands represent carrier specific bands. The shifts in bold are those that have been apparently changed after immobilization. B) Raman imaging of the immobilized biocatalyst. On the left, the bright field image of the portion of the sample analyzed by Raman imaging. On the side (top), the Raman map of the immobilized biocatalyst produced by merging the signals obtained by the two reference samples (enzyme-green and carrier-blue). On the side (middle, bottom), the Raman maps reporting the signals of the single components.

$\gamma$-glutamylmethionine in Tris- $\mathrm{HCl}$ buffer $(\mathrm{pH} 9,0.05 \mathrm{M}) .{ }^{[33]}$ After each reaction cycle ( 3 days), the reaction mixture was filtered under reduced pressure and the immobilized biocatalyst was re-used for the following reaction runs. As depicted in Figure 4, the immobilized ekGGT was successfully re-used for 6 cycles (18 days) and retained about $80 \%$ of its activity, thus showing an optimal recyclability. This result suggests that OCGLXagarose-ekGGT could be re-used for additional reactions. Furthermore, it is worth pointing out that immobilization
120

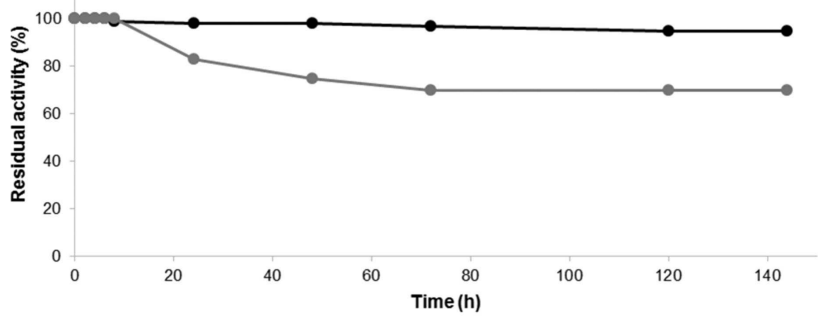

Figure 3. Stability of native ekGGT and OCGLX-agarose-ekGGT.

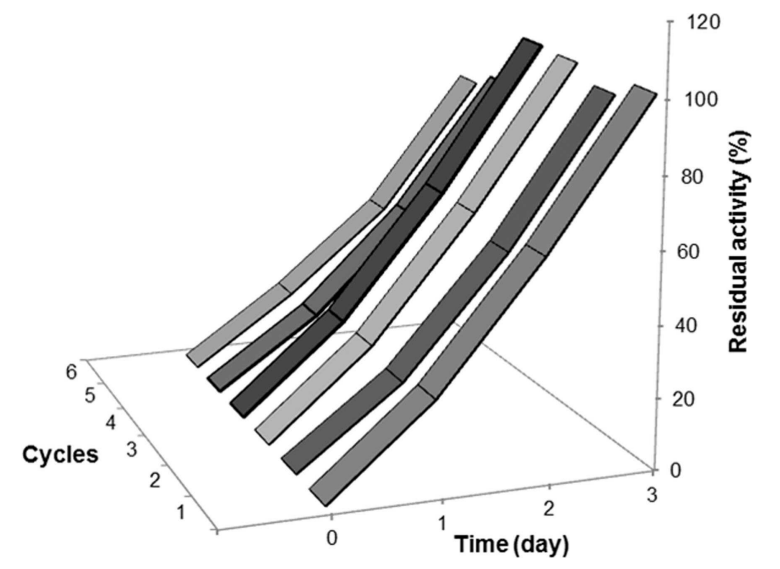

Figure 4. Biocatalyst recycling. Synthesis of $\gamma$-glutamylmethionine catalyzed by OCGLX-agarose-ekGGT.

applied to ekGGT exerted more than the "usual" advantages derived from the heterogeneous catalysis (i.e. recyclability, reuse, protein stabilization, control of the process). In fact, ekGGT is a paradigmatic example of how immobilization can be also a viable technique to offset the high costs associated with production and use of expensive and hardly available enzymes (ekGGT is not a recombinant protein but it is extracted from natural sources in a low yield).

\subsection{Preparative Synthesis of $\gamma$-Glutamylmethionine}

In order to demonstrate the feasibility of a true biocatalytic application with the immobilized ekGGT, OCGLX-agarose-ekGGT was used to catalyze the synthesis of $\gamma$-glutamylmethionine also at a preparative scale. $5 \mathrm{U}$ of OCGLX-agarose-ekGGT were added to a L-methionine solution ( $333 \mathrm{mM})$ in Tris- $\mathrm{HCl}$ buffer $(\mathrm{pH} 9,0.05 \mathrm{M})$ in the presence of a $10 \%$ molar excess GSH. After 72 hours, $^{[33]}$ the reaction product was isolated by preparative ion exchange chromatography in $42 \%$ yield. This result was consistent with the data obtained by using the non-immobilized enzyme. ${ }^{[33]}$ 


\section{Conclusions}

In this work, we have developed a tailor-made immobilization for ekGGT, a membrane enzyme which can be used for the synthesis of $\gamma$-glutamyl amino acids having a great interest for food applications. $\gamma$-Glutamylmethionine was used as the reference kokumi compound to demonstrate the feasibility of the ekGGT-catalyzed synthetic application and the excellent recyclability/stability of the biocatalyst. The heterofunctional carrier OCGLX-agarose ${ }^{[34]}$ conveys hydrophobic alkyl chains and aldehyde groups which result in a concurrent noncovalent and covalent immobilization of the protein. On one hand, enzyme-carrier hydrophobic interactions, mimicking what occurs in vivo when the enzyme is anchored to the lipid membrane, are assumed to stabilize the tertiary folded structure of the protein, on the other hand, the formation of stable $\mathrm{C}-\mathrm{N}$ bonds between the enzyme and the carrier further stabilizes the protein which can be thus used also in non-conventional environments.

A key issue in developing an immobilized enzyme for biocatalytic applications also includes a strict control of all the numerous variables associated with the immobilization protocol. In this frame, the Placket-Burmann design has clearly highlighted which were the critical factors and the corrections needed in order to set up a robust and reproducible immobilization procedure.

\section{Experimental Section}

$\gamma$-Glutamyl transpeptidase from equine kidney (ekGGT), octylSepharose ${ }^{\oplus}$ CL-4B (octyl-agarose, OC-agarose), L-glutamic acid $\gamma$ (4-nitroanilide) (GpNA), glycylglycine (Gly-Gly), 4-nitroaniline, Lmethionine, glutathione (GSH), Bradford reagent, cyanogen bromide activated-Sepharose ${ }^{\circledast} 4 \mathrm{~B}$ (CNBr-agarose), glycidol, sodium periodate $\left(\mathrm{NaIO}_{4}\right)$, sodium borohydride $(\mathrm{NaBH} 4)$, ethylenediamine (EDA), glutaraldehyde (GA), 3-aminopropyl-triethoxysilane (APTES), 3-glycidyloxypropyl-trimethoxysilane (GPTS), triethylamine $\left(\mathrm{Et}_{3} \mathrm{~N}\right)$, potassium phosphate, $N, N^{\prime}$-carbonyldiimidazole (CDI), Dowex $1 \times 8$ ion exchange resin pad (200-400 mesh), ninhydrin reagent were purchased from Sigma Aldrich (Milano, Italy). Analytical thin layer chromatography (TLC) was performed on silica gel F254 precoated aluminium sheets $(0.2 \mathrm{~mm}$ layer, Merck, Darmstadt, Germany). Sepharose ${ }^{\mathrm{TM}} \mathrm{CL}-6 \mathrm{~B}$ (agarose) was from Amersham Biosciences (Uppsala, Sweden). Sepabeads ${ }^{T M}$ EC$E P / S$ was a gift of Resindion S.r.I (Binasco, Italy). Sodium bicarbonate was from Carlo Erba (Cornaredo, Italy). Spectrophotometric assays were performed using a Shimadzu UV-1601 UVVisible spectrophotometer equipped with magnetic stirring. Raman and UV-Vis spectroscopy was performed with a Aramis Horiba Jobin-Yvon micro-Raman spectrometer equipped with solid state lasers operating at $633 \mathrm{~nm}$ and $785 \mathrm{~nm}$ and with a Duoscan mapping mode configuration.

\section{ekGGT Activity Assay}

The standard activity assay $(2 \mathrm{~mL})$ was performed at room temperature in Tris- $\mathrm{HCl}$ buffer $(\mathrm{pH} 8.5,0.1 \mathrm{M})$ containing GpNA (0.001 M), Gly-Gly $(0.1 \mathrm{M}$ ) and an appropriate amount of enzyme (free ekGGT: $1 \mu \mathrm{g}$; immobilized ekGGT: $5-15 \mathrm{mg}$, under magnetic stirring). The reaction was monitored spectrophotometrically by measuring the formation of 4-nitroaniline at $410 \mathrm{~nm}$ in kinetic mode. ${ }^{[41]}$ The amount of 4-nitroaniline produced by the enzyme was quantified by using a calibration curve and a extinction coefficient of $8300 \mathrm{M}^{-1}$ $\mathrm{cm}^{-1}$. One unit of ekGGT was defined as the amount of enzyme that produces $1 \mu$ mole of 4-nitroaniline per minute from GpNA in the presence of the acceptor Gly-Gly. The protein content in the solid crude extract of ekGGT was $50 \%$ of its weight based on Bradford assay; ${ }^{[42]}$ all the activity data reported in this paper are referred to this percentage.

\section{Preparation of Agarose based Carriers}

Glyoxyl-agarose (GLX-agarose) was prepared as reported in literature. $^{[43]}$ Briefly, Sepharose ${ }^{\mathrm{TM}} \mathrm{CL}-6 \mathrm{~B}$ (agarose, $5 \mathrm{~g}$ ) was suspended in $\mathrm{dH}_{2} \mathrm{O}(1.4 \mathrm{~mL})$ and $\mathrm{NaOH}(1.7 \mathrm{M}, 2.4 \mathrm{~mL})$ containing $\mathrm{NaBH}_{4}\left(28.4 \mathrm{mg} \mathrm{mL}^{-1}\right)$. Subsequently, glycidol $(1.7 \mathrm{~mL})$ was added dropwise keeping the vessel at $4^{\circ} \mathrm{C}$ in an ice bath. The reaction was kept under gently stirring overnight at $25^{\circ} \mathrm{C}$. After the incubation period, the suspension was filtered and the carrier was washed abundantly with $\mathrm{dH}_{2} \mathrm{O}$. Oxidation was initiated by adding $\mathrm{NaIO}_{4}(0.1 \mathrm{M}, 34 \mathrm{~mL})$. The reaction was carried out for 2 hours at room temperature, then the carrier was filtered under reduced pressure and washed abundantly with $\mathrm{dH}_{2} \mathrm{O}$ and stored at $4{ }^{\circ} \mathrm{C}$.

GA-EDA-agarose was prepared as described in literature. ${ }^{[36]} \mathrm{GLX}$ agarose $(2 \mathrm{~g})$ was aminated using EDA $(\mathrm{pH} 10,2 \mathrm{M}, 11.43 \mathrm{~mL})$ for 2 hours and subsequently reduced for 2 hours with $\mathrm{NaBH}_{4}$ $(11.4 \mathrm{mg})$. The EDA-activated agarose was then suspended in $\mathrm{KH}_{2} \mathrm{PO}_{4}$ buffer $(\mathrm{pH} 7,0.2 \mathrm{M}, 2.3 \mathrm{~mL})$ and a solution of $\mathrm{GA}(25 \%(\mathrm{v} / \mathrm{v})$ in $\mathrm{dH}_{2} \mathrm{O}, 3.4 \mathrm{~mL}$ ) was added. The mixture was kept under mechanical stirring for 16 hours at room temperature in the darkness. The activated carrier was washed abundantly with $\mathrm{dH}_{2} \mathrm{O}$ and stored at $4^{\circ} \mathrm{C}$.

GA-APTES-agarose was prepared by modifying a protocol described in literature. ${ }^{[4]}$ Briefly, Sepharose ${ }^{\mathrm{TM}} \mathrm{CL}-6 \mathrm{~B}$ (agarose, $3 \mathrm{~g}$ ) was suspended in $\mathrm{NaOH}(0.5 \mathrm{M}, 50 \mathrm{~mL})$ for 2 hours. The carrier was filtered, washed with $\mathrm{dH}_{2} \mathrm{O}$ and activated with APTS $(10 \%(\mathrm{v} / \mathrm{v})$ in $\mathrm{dH}_{2} \mathrm{O}, 60 \mathrm{~mL}$ ) for 24 hours. Then, the carrier was washed and suspended in $\mathrm{KH}_{2} \mathrm{PO}_{4}$ buffer $(\mathrm{pH} 7,0.2 \mathrm{M}, 10 \mathrm{~mL})$ and $\mathrm{GA}(25 \% \mathrm{v} / \mathrm{v}$ in $\mathrm{dH}_{2} \mathrm{O}, 6 \mathrm{~mL}$ ). The mixture was kept under stirring for 16 hours at room temperature in the darkness.

GPTS-agarose was prepared as described in literature. ${ }^{[45]}$ Briefly, dry agarose $(3 \mathrm{~g})$ was suspended in dry toluene $(60 \mathrm{~mL})$. Subsequently, GPTS $(3 \mathrm{~mL})$ and $\mathrm{Et}_{3} \mathrm{~N}(0.45 \mathrm{~mL})$ were added and the reaction was kept for 24 hours at room temperature under stirring. The resulting carrier was filtered, washed and dried at $50^{\circ} \mathrm{C}$ for 3 hours.

$\mathrm{CDI}$-agarose was prepared by modifying the protocol described in literature. ${ }^{[46,47]}$ Sepharose ${ }^{\mathrm{TM}}$ CL-6B (agarose, $3 \mathrm{~g}$ ) was suspended in dry acetone $(50 \mathrm{~mL})$ and $\mathrm{CDI}(5 \mathrm{~g})$ was added. The mixture was kept under stirring overnight at room temperature. The resulting carrier was filtered, washed and dried at $50^{\circ} \mathrm{C}$ for 3 hours.

Commercial cyanogen bromide-activated-Sepharose ${ }^{\oplus}$ 4B (CNBragarose) (1 g) was hydrated in $\mathrm{HCl}(0.001 \mathrm{M}, 200 \mathrm{~mL})$ for 30 minutes. Then it was washed using $\mathrm{NaHCO}_{3}$ buffer $(\mathrm{pH} 8,0.1 \mathrm{M})$ and used for the immobilization procedure.

OCGLX-agarose was prepared by octyl-Sepharose ${ }^{\circledast}$ CL-4B (OCagarose) oxidation as reported in literature. ${ }^{[34]}$ The glyceryl groups of OC-agarose ( $1 \mathrm{~g}$ ) were oxidized using $\mathrm{NaIO}_{4}(35 \mu \mathrm{mol})$ for 2 hours at room temperature under stirring. The oxidation degree of the carrier was monitored spectrophotometrically by the periodate assay of the supernatant. ${ }^{[43]}$ Following this procedure, the carrier 
was functionalized with $25-30 \mu \mathrm{mol}$ aldehyde groups per gram of carrier.

\section{ekGGT Immobilization}

For all the immobilization procedures, an enzyme loading of $1 \mathrm{mg}$ was used per gram of carrier. A 10:1 ratio volume of immobilization reaction/volume of the carrier was used. The protein content in the solid crude extract of ekGGT was $50 \%$ of its weight based on Bradford assay. ${ }^{[42]}$ During immobilization, the supernatant was monitored by measuring the amount of protein in solution (Bradford assay ${ }^{[42]}$ ), and the residual activity of the supernatant $(20 \mu \mathrm{L})$ was checked by the standard activity assay described before.

Immobilization of ekGGT on GLX-agarose was performed following the standard protocol. ${ }^{[43]}$ Briefly, GLX-agarose was washed abundantly with $\mathrm{NaHCO}_{3}$ buffer $(\mathrm{pH} 10,0.05 \mathrm{M})$ and then filtered under reduced pressure until dryness. The solid crude extract of ekGGT $\left(400 \mu \mathrm{g}, 200 \mu \mathrm{g}\right.$ of protein) were solubilized into $\mathrm{NaHCO}_{3}$ buffer $(2.52 \mathrm{~mL})$. Then, the carrier $(200 \mathrm{mg})$ was added and the suspension was allowed to stir for 4 hours at room temperature. Finally, $\mathrm{NaBH}_{4}$ $(2.5 \mathrm{mg})$ was added to the mixture and incubated for 30 minutes for imino bonds reduction. The immobilized enzyme was then filtered, washed with Tris- $\mathrm{HCl}$ buffer $(\mathrm{pH} 8.5,0.1 \mathrm{M})$ and stored at $4^{\circ} \mathrm{C}$.

The immobilization of ekGGT on GA-EDA-agarose and GA-APTESagarose was carried out in $\mathrm{NaHCO}_{3}$ buffer (pH 10, $0.05 \mathrm{M}$ ), while the immobilization on GPTS-agarose and CDI-agarose was performed in $\mathrm{KH}_{2} \mathrm{PO}_{4}$ buffer $(\mathrm{pH} 8,0.05 \mathrm{M})$. The solid crude extract of ekGGT $(500 \mu \mathrm{g}, 250 \mu \mathrm{g}$ of protein) was solubilized in the suitable buffer $(3.15 \mathrm{~mL})$ and added to the activated carrier $(250 \mathrm{mg})$; the suspension was allowed to stir at room temperature. After 24 hours, the carrier was filtered under reduced pressure, washed with Tris$\mathrm{HCl}$ buffer $(\mathrm{pH} 8.5,0.1 \mathrm{M})$ and stored at $4{ }^{\circ} \mathrm{C}$.

The immobilization of ekGGT on CNBr-agarose was performed following a standard procedure. ${ }^{[36]}$ ekGGT solid crude extract $\left(540 \mu \mathrm{g}, 270 \mu \mathrm{g}\right.$ of protein) was dissolved in $\mathrm{NaHCO}_{3}$ buffer ( $\mathrm{pH} 8$, $0.1 \mathrm{M}, 3.5 \mathrm{~mL}$ ). Subsequently, the hydrated carrier $(270 \mathrm{mg})$, prepared as previously described, was added. After 3 hours, the immobilized biocatalyst was filtered and suspended in Tris- $\mathrm{HCl}$ buffer $(\mathrm{pH} 8,0.1 \mathrm{M}, 3.5 \mathrm{~mL}$ ) for 2 hours. Then, the immobilized biocatalyst was washed with Tris- $\mathrm{HCl}$ buffer $(\mathrm{pH} 8.5,0.1 \mathrm{M})$ and stored at $4^{\circ} \mathrm{C}$.

The immobilization protocol on OCGLX-agarose was carried out in two steps: first, the protein was adsorbed to the carrier, then the reaction between the carrier aldehydes and the enzyme amino groups took place. ${ }^{[34]}$ OCGLX-agarose was washed with $\mathrm{KH}_{2} \mathrm{PO}_{4}$ buffer (pH 7, $0.025 \mathrm{M})$. ekGGT solid crude extract ( $500 \mu \mathrm{g}, 250 \mu \mathrm{g}$ of protein) was solubilized in the same buffer $(3.15 \mathrm{~mL})$ in the presence of the carrier $(250 \mathrm{mg}){ }^{[48]}$ After 3 hours, all the protein in solution was absorbed onto the carrier; the biocatalyst was filtered and suspended in $\mathrm{NaHCO}_{3}$ buffer ( $\mathrm{pH} \mathrm{10,0.05} \mathrm{M,} \mathrm{3.15} \mathrm{mL).} \mathrm{Immobi-}$ lization was carried on for further 3 hours and then $\mathrm{NaBH}_{4}(3 \mathrm{mg})$ was added. After stirring for 30 minutes, the biocatalyst was washed with Tris- $\mathrm{HCl}$ buffer $(\mathrm{pH} 8.5,0.1 \mathrm{M})$ and stored at $4{ }^{\circ} \mathrm{C}$. For the preparative synthesis of $\gamma$-glutamylmethionine the protein loading was scaled-up to $2 \mathrm{mg} \mathrm{g}^{-1}$.

Immobilization on Sepabeads ${ }^{\mathrm{TM}}$ EC-EP/S was performed as reported in literature. ${ }^{[49,50]}$ Commercial Sepabeads ${ }^{\mathrm{TM}}$ EC-EP/S was hydrated with $\mathrm{dH}_{2} \mathrm{O}$ for 1 hour under mechanical stirring. Then, the carrier was washed with $\mathrm{KH}_{2} \mathrm{PO}_{4}$ buffer $(\mathrm{pH} 8,1 \mathrm{M})$. ekGGT solid crude extract $(500 \mu \mathrm{g}, 250 \mu \mathrm{g}$ of protein) was solubilized in the same buffer $(3.15 \mathrm{~mL})$ and the carrier $(250 \mathrm{mg})$ was added to the solution. After 24 hours, the carrier was filtered and resuspended in $\mathrm{KH}_{2} \mathrm{PO}_{4}$ buffer $(\mathrm{pH} 8,1 \mathrm{M}, 3.15 \mathrm{~mL})$ containing glycine $(3 \mathrm{M})$ for the quenching step. After 21 hours, the immobilized biocatalyst was washed with Tris- $\mathrm{HCl}$ buffer $(\mathrm{pH} 8.5$, $0.1 \mathrm{M})$ and stored at $4{ }^{\circ} \mathrm{C}$.

\section{Plackett-Burman Design}

The first experiments of immobilization were performed using freshly prepared OCGLX-agarose (one day before starting the experiments). On the day one, 4 experiments were carried out (reactions 2, 3, 5 and 8, Table 2). Specifically, ekGGT (1.6 mg) was dissolved in $\mathrm{KH}_{2} \mathrm{PO}_{4}$ buffer $(\mathrm{pH} 7,0.025 \mathrm{M}, 0.8 \mathrm{~mL})$; meanwhile the carrier was conditioned with the same buffer and $200 \mathrm{mg}$ of OCGLX-agarose were used for each immobilization trial. Phosphate buffer $(\mathrm{pH} 7,0.025 \mathrm{M})$ was added in a vessel $(4 \mathrm{~mL}$ or $2 \mathrm{~mL})$ for reactions 5 and 8 , respectively, followed by the ekGGT solution $(0.2 \mathrm{~mL})$. Both the reactions were kept under mechanical stirring. The same procedure was carried out for reactions 2 and $3(4 \mathrm{~mL}$ or $2 \mathrm{~mL}$, respectively) but in this case, the reactions were stirred by a rotary shaker. After 3 hours, solid $\mathrm{NaBH}_{4}\left(1 \mathrm{mg} \mathrm{mL}^{-1}\right)$ was added to reactions 5 and 8 . After $30 \mathrm{~min}$, reaction 8 was filtered and washed with Tris- $\mathrm{HCl}$ buffer $(\mathrm{pH} 8.5,0.1 \mathrm{M})$ and dried for $3 \mathrm{~min}$. The same procedure was performed for reaction 5 , but prolonging to $60 \mathrm{~min}$ the chemical reduction step. In this case, the immobilized ekGGT was filtered and dried s.v. for 10 min. For reactions 2 and $3, \mathrm{NaBH}_{4}$ was dissolved in water $\left(2 \mathrm{mg} \mathrm{mL}^{-1}\right)$ prior to addition to the reaction mixture $(4 \mathrm{~mL}$ and $2 \mathrm{~mL}$, respectively). After $30 \mathrm{~min}$, reaction 2 was filtered, washed with Tris- $\mathrm{HCl}$ buffer $(\mathrm{pH} 8.5,0.1 \mathrm{M})$ and dried for $10 \mathrm{~min}$, whereas the reduction step for reaction 3 was $60 \mathrm{~min}$ and the drying time of the biocatalyst after filtration s.v. was 3 min. The standard activity assay was performed twice on each of the 4 immobilized biocatalysts.

The immobilization was also performed using OCGLX-agarose stored at $4^{\circ} \mathrm{C}$ for one week. On the seventh day, 4 experiments were carried out (reactions 1, 4, 6 and 7, Table 2). Specifically, ekGGT $(1.6 \mathrm{mg})$ was dissolved in $\mathrm{KH}_{2} \mathrm{PO}_{4}$ buffer $(\mathrm{pH} 7,0.025 \mathrm{M}$ $0.8 \mathrm{~mL}$ ); meanwhile the carrier was conditioned with the same buffer and $200 \mathrm{mg}$ of OCGLX-agarose were used for each immobilization trial. Phosphate buffer $(\mathrm{pH} 7,0.025 \mathrm{M})$ was added in a vessel ( $2 \mathrm{~mL}$ or $4 \mathrm{~mL}$ ) for reactions 4,6 and 1, 7, respectively, followed by the ekGGT solution $(0.2 \mathrm{~mL})$. Reactions 4 and 7 were kept under mechanical stirring while reactions 6 and 1 were stirred by a rotary shaker. After 3 hours, to reactions 4 and 7, an appropriate volume of an aqueous stock solution of $\mathrm{NaBH}_{4}\left(2 \mathrm{mg} \mathrm{mL}^{-1}\right)$ was added in order to reach a final concentration of $1 \mathrm{mg} \mathrm{mL}^{-1}$. After $30 \mathrm{~min}$, reaction 7 was filtered, washed with Tris- $\mathrm{HCl}$ buffer $(\mathrm{pH} 8.5,0.1 \mathrm{M})$ and dried for $3 \mathrm{~min}$, whereas the reduction step for reaction 4 was $60 \mathrm{~min}$ and the drying time of the biocatalyst after filtration s.v. was 10 min. Reactions 1 and 6 were incubated with solid $\mathrm{NaBH}_{4}$ $\left(1 \mathrm{mg} \mathrm{mL}^{-1}\right)$ for $60 \mathrm{~min}$ and $30 \mathrm{~min}$, respectively. After the chemical reduction step, reactions 1 and 6 were washed and dried s.v. for 3 and $10 \mathrm{~min}$, respectively. The standard activity assay was performed twice on each of the 4 immobilized biocatalysts.

\section{Raman Spectroscopy}

The enzyme (ekGGT), the carrier (OCGLX-agarose), and the immobilized biocatalyst (OCGLX-agarose-ekGGT) were analyzed by a Raman microspectroscope equipped with a diode-pumped solidstate laser operating at $532 \mathrm{~nm}$ and a Peltier-cooled CCD detector. Each sample was deposited on a calcium fluoride slide and allowed to air dry. All the measurements were performed with $100 \times$ objective (NA 0.75, Olympus, Tokyo, Japan), 1800 grooves $/ \mathrm{mm}$ diffraction grating, $400 \mu \mathrm{m}$ entrance slit, and confocal mode 
(600 $\mu \mathrm{m}$ pinhole) in the spectral ranges $500-1800 \mathrm{~cm}^{-1}$ and 2600 $3200 \mathrm{~cm}^{-1}$. Accumulation times were $2 \times 10 \mathrm{~s}$ per spectrum. The Raman shift was calibrated automatically using LabSpec 6 software (Horiba) using zero order line and Si line of a Si reference sample. In order to capture the spectra randomly, maps of about $150 \mu \mathrm{m}^{2}$ (with lateral steps of 20-30 $\mu \mathrm{m}$ ) were acquired in the centre and at the borders of the samples.

\section{ekGGT Stability}

The enzyme stability was evaluated in Tris- $\mathrm{HCl}$ buffer $(0.05 \mathrm{M}$ $\mathrm{pH}$ 9.0) during a 6-day period at $4{ }^{\circ} \mathrm{C}$. The samples were periodically withdrawn and their activities were measured by the standard activity assay described before. After 6 day-incubation, no protein release from the carrier was detected, as indicated by the absence of protein in the supernatant (Bradford assay ${ }^{[42]}$ ).

\section{ekGGT Recycling}

The recycle of immobilized ekGGT was performed according to the procedure described in literature. ${ }^{[33]}$ One glass sample holder with a stirring bar was filled with L-methionine (149 mg, $1.0 \mathrm{mmol}$ ) and GSH (338 mg, $1.1 \mathrm{mmol})$. L-Methionine and GSH were solubilized in Tris- $\mathrm{HCl}$ buffer $(\mathrm{pH} \mathrm{9,0.05} \mathrm{M,} 1 \mathrm{~mL})$ under stirring. The $\mathrm{pH}$ was adjusted to 9 with $\mathrm{NaOH}(2 \mathrm{M})$ and stirring was maintained until the solution was completely clear. Afterwards, $2 \mathrm{~mL}$ of the same buffer were added to the reaction mixture. A specific amount of immobilized biocatalyst $(5 \mathrm{U})$ was added. The mixture was kept at $4{ }^{\circ} \mathrm{C}$ under stirring for 3 days. The reaction mixture was filtered on a Büchner funnel s.v. and the immobilized biocatalyst was re-used for the second reaction run. The residual activity of immobilized ekGGT was measured by the standard activity assay described before.

\section{Preparative Synthesis of $\boldsymbol{\gamma}$-Glutamylmethionine}

L-Methionine (149 mg, $1.0 \mathrm{mmol})$ and GSH (338 mg, $1.1 \mathrm{mmol})$ were suspended in Tris- $\mathrm{HCl}$ buffer $(\mathrm{pH} 8.5,0.05 \mathrm{M}$, ca $1 \mathrm{~mL})$. The $\mathrm{pH}$ was adjusted to 9.0 with $\mathrm{NaOH}(2 \mathrm{M})$ until a clear solution was obtained, then the solution was diluted to a final volume of $3 \mathrm{~mL}$ with the same buffer. The reaction was initiated by addition of the immobilized enzyme $(5 \mathrm{U})$. After 72 hours at $4{ }^{\circ} \mathrm{C}$, the reaction was filtered to remove the immobilized enzyme and the $\mathrm{pH}$ of the reaction mixture was adjusted to $9.5-10$ with $\mathrm{NaOH}$ $(2 \mathrm{M})$; the solution was charged onto a Dowex $1 \times 8$ ion exchange resin pad (200-400 mesh) in the acetate form. The resin pad $(14 \mathrm{~cm})$ was conditioned with glacial acetic acid (6 volumes) and washed abundantly with water (20 volumes; until the $\mathrm{pH}$ was almost neutral). The elution was performed with $\mathrm{CH}_{3} \mathrm{COOH}$ $(0.1 \mathrm{M}, 0.25 \mathrm{M}, 0.5 \mathrm{M}$ and $2 \mathrm{M}$; three column volumes each). Unreacted L-methionine was eluted in the void volume and in the first volume of $0.1 \mathrm{M} \mathrm{CH}_{3} \mathrm{COOH}, \gamma$-glutamylmethionine was eluted between $0.25 \mathrm{M}$ and $0.5 \mathrm{M}$, while unreacted GSH was eluted with $2 \mathrm{M} \mathrm{CH} \mathrm{CH}_{3} \mathrm{COOH}$. Fractions containing the desired product were checked by TLC, combined and dried under vacuum (yield: $42 \%, 101 \mathrm{mg}$ ). The mobile phase used for TLC analysis was $n$-butanol/ $\mathrm{dH}_{2} \mathrm{O} /$ acetic acid $(4: 1: 1)$. TLC were eluted twice and analyte detection was performed by using $1 \%$ $\mathrm{v} / \mathrm{v}$ ninhydrin in ethanol. ${ }^{1} \mathrm{H}-\mathrm{NMR}$ and ESI-MS analyses were in agreement with literature data. ${ }^{[33]}$

\section{Acknowledgements}

This research was funded by Cariplo Foundation (Italy) "Valueadded products through biocatalysis: tailored $\gamma$-glutamyltranspeptidases" (TailGluTran, ID 2016-0741).

\section{Conflict of Interest}

The authors declare no conflict of interest.

Keywords: $\gamma$-glutamyl transpeptidase - kokumi peptides enzyme immobilization · octyl-glyoxyl-agarose · experimental design

[1] S. Raveendran, B. Parameswaran, S. B. Ummalyma, A. Abraham, A. K. Mathew, A. Madhavan, S. Rebello, A. Pandey, Food Technol. Biotechnol. 2018, 56, 16-30.

[2] J. Chapman, A. Ismail, C. Dinu, Catalysts 2018, 8, 1-26.

[3] M. D. Truppo, ACS Med. Chem. Lett. 2017, 8, 476-480.

[4] S. Cantone, V. Ferrario, L. Corici, C. Ebert, D. Fattor, P. Spizzo, L. Gardossi, Chem. Soc. Rev. 2013, 42, 6262-6276.

[5] R. DiCosimo, J. McAuliffe, A. J. Poulose, G. Bohlmann, Chem. Soc. Rev. 2013, 42, 6437-6474.

[6] A. A. Ajayi, E. A. Onibokun, Research 2017, 9, 1-7.

[7] A. S. Bommarius, M. F. Paye, Chem. Soc. Rev. 2013, 42, 6534-6565.

[8] E. Cappannella, I. Benucci, C. Lombardelli, K. Liburdi, T. Bavaro, M. Esti, Food Chem. 2016, 210, 49-55.

[9] M. Ružič, A. Pečavar, D. Prudič, D. Kralj, C. Scriban, A. Zanotti-Gerosa, Org. Process Res. Dev. 2012, 16, 1293-1300.

[10] R. A. Sheldon, S. van Pelt, Chem. Soc. Rev. 2013, 42, 6223-6235.

[11] A. E. Rawlings, Biochem. Soc. Trans. 2016, 44, 790-795.

[12] O. Vit, J. Petrak, J. Proteomics 2017, 153, 8-20.

[13] V. Früh, A. P. IJzerman, G. Siegal, Chem. Rev. 2011, 111, 640-656.

[14] N. Bistolas, U. Wollenberger, C. Jung, F. W. Scheller, Biosens. Bioelectron. 2005, 20, 2408-2423.

[15] C. S. Pundir, N. Chauhan, Anal. Biochem. 2012, 429, 19-31.

[16] F. Fiorentini, M. Geier, C. Binda, M. Winkler, K. Faber, M. Hall, A. Mattevi, ACS Chem. Biol. 2016, 11, 1039-1048.

[17] T. Ito, R. Sadamoto, K. Naruchi, H. Togame, H. Takemoto, H. Kondo, S.-I. Nishimura, Biochemistry 2010, 49, 2604-2614.

[18] O. Lenz, M. Ludwig, T. Schubert, I. Bürstel, S. Ganskow, T. Goris, A. Schwarze, B. Friedrich, ChemPhysChem 2010, 11, 1107-1119.

[19] T. Gotoh, M. Shidara, M. Hozawa, J. Ferment. Bioeng. 1994, 77, 268-273.

[20] I. Mazurenko, W. Ghach, G.-W. Kohring, C. Despas, A. Walcarius, M. Etienne, Bioelectrochemistry 2015, 104, 65-70.

[21] E. Nazaruk, E. M. Landau, R. Bilewicz, Electrochim. Acta 2014, 140, 96100.

[22] W. Sun, J. J. Vallooran, W.-K. Fong, R. Mezzenga, J. Phys. Chem. Lett. 2016, 7, 1507-1512.

[23] M. Oelschlägel, A. Riedel, A. Zniszczoł, K. Szymańska, A. B. Jarzębski, M. Schlömann, D. Tischler, J. Biotechnol. 2014, 174, 7-13.

[24] H. Hoi, A. Jiménez Castellanos, M. Aminpour, Y. He, H. Zhou, S. Abraham, C. D. Montemagno, Chem. Commun. 2018, 54, 1889-1892.

[25] A. Donald, in Methods in Enzymology, Academic Press, Cambridge, MA, 1985, pp. 419-437.

[26] A. Meister, S. S. Tate, O. W. Griffith, in Methods in Enzymology, Academic Press, Cambridge, MA, 1981, pp. 237-253.

[27] N. Taniguchi, Y. Ikeda, in Advances in Enzymology and Related Areas of Molecular Biology (Ed.: D. L. Purich), John Wiley \& Sons, Hoboken, NJ, 1998, pp. 239-278.

[28] G. A. Thompson, A. Meister, Biochem. Biophys. Res. Commun. 1976, 71, 32-36.

[29] S. S. Tate, A. Meister, Mol. Cell. Biochem. 1981, 39, 357-368.

[30] H. Suzuki, C. Yamada, K. Kato, Amino Acids 2007, 32, 333-340.

[31] A. Dunkel, J. Köster, T. Hofmann, J. Agric. Food Chem. 2007, 55, 67126719.

[32] L.-L. Lin, M.-C. Chi, Y.-J. Lan, M.-G. Lin, T.-Y. Juang, T.-F. Wang, Int. J. Biol. Macromol. 2018, 117, 1326-1333. 
[33] G. Speranza, C. F. Morelli, J. Mol. Catal. B 2012, 84, 65-71.

[34] N. Rueda, J.C. S. dos Santos, R. Torres, C. Ortiz, O. Barbosa, R. Fernandez-Lafuente, RSC Adv. 2015, 5, 11212-11222.

[35] P. Zucca, R. Fernandez-Lafuente, E. Sanjust, Molecules 2016, 21, 1577.

[36] T. Bavaro, G. Cattaneo, I. Serra, I. Benucci, M. Pregnolato, M. Terreni, Molecules 2016, 21, 1621.

[37] M. Terreni, D. Ubiali, T. Bavaro, M. Pregnolato, R. Fernández-Lafuente, J. M. Guisán, Appl. Microbiol. Biotechnol. 2007, 77, 579-587.

[38] C. Temporini, P. Bonomi, I. Serra, A. Tagliani, T. Bavaro, D. Ubiali, G. Massolini, M. Terreni, Biomacromolecules 2010, 11, 1623-1632.

[39] P. Bonomi, T. Bavaro, I. Serra, A. Tagliani, M. Terreni, D. Ubiali, Molecules 2013, 18, 14349-14365.

[40] A. C. S. Talari, Z. Movasaghi, S. Rehman, I. ur Rehman, Appl. Spectrosc. Rev. 2015, 50, 46-111.

[41] S. S. Tate, A. Meister, Methods Enzymol. 1985, 113, 400-419.

[42] M. M. Bradford, Anal. Biochem. 1976, 72, 248-254.

[43] J. M. Guisán, Enzyme Microb. Technol. 1988, 10, 375-382.

[44] E. Calleri, G. Cattaneo, M. Rabuffetti, I. Serra, T. Bavaro, G. Massolini, G. Speranza, D. Ubiali, Adv. Synth. Catal. 2015, 357, 2520-2528.
[45] M. Babaki, M. Yousefi, Z. Habibi, J. Brask, M. Mohammadi, Biochem. Eng. J. 2015, 101, 23-31.

[46] J. Ho, F. M. N. Al-Deen, A. Al-Abboodi, C. Selomulya, S. D. Xiang, M. Plebanski, G. M. Forde, Colloids Surf. B 2011, 83, 83-90.

[47] M. T. W. Hearn, in Methods in Enzymology, Academic Press, Cambridge, MA, 1987, pp. 102-117.

[48] T. Bavaro, D. Ubiali, S. Brocca, S. Rocchietti, I. Nieto, M. Pregnolato, M. Lotti, M. Terreni, Biocatal. Biotransform. 2010, 28, 108-116.

[49] M. Petenzi, T. Bavaro, C. Cornaggia, D. Ubiali, M. Pregnolato, D. Pasini, Polym. Int. 2012, 61, 1611-1618.

[50] I. Benucci, M. Esti, K. Liburdi, A. M. V. Garzillo, Biotechnol. Prog. 2012, 28, 1472-1477.

Manuscript received: August 9, 2019

Revised manuscript received: September 24, 2019

Accepted manuscript online: September 27, 2019

Version of record online: November 12, 2019 